\title{
Implementasi Metode Dempster Shafer Analytic Hierarchy Process Untuk Pemilihan Program Studi Calon Mahasiswa
}

\author{
Menur Wahyu Pangestikaa,," Oky Dwi Nurhayati ${ }^{\mathrm{b}}$, Suryono ${ }^{\mathrm{c}}$ \\ ${ }^{a}$ Mahasiswa Magister Sistem Informasi Universitas Diponegoro \\ ${ }^{\mathrm{b}}$ Fakultas Teknik, Universitas Diponegoro \\ ${ }^{\mathrm{c}}$ Fakultas Sains dan Matematika, Universitas Diponegoro
}

Naskah Diterima : 7 Maret 2016; Diterima Publikasi : 29 Maret 2016

DOI: $10.21456 /$ vol6iss1pp11-20

\begin{abstract}
Methods Dempster Shafer Analytic Hierarchy Process is used to rank or sort information based on a number of criteria. DS/AHP advantage of Pairwise Comparison, Consistency Ratio, and Dempster Rule's of Combination, which is used to generate information systems in the form of a sequence of courses as consideration for the selection of majors for prospective students. The sample used in this study were 29 students of five faculty at the University of Diponegoro. The data used is the standard minimum value of each faculty and the average value of the semester report card 1-5 Mathematics, Indonesian, English, Biology, Chemistry, and Physics. Results of this study was the software selection study program that gives students the value of trust in each department. Testing the validity of the value of the accuracy of the system is done by comparing the majors were chosen with the recommendation majors produced by the system, resulting accuracy of $79.33 \%$.
\end{abstract}

Keywords : Dempster shafer analytic hierarchy process; Department recommendations; Standard minimum value; Average of value report

\begin{abstract}
Abstrak
Metode Dempster Shafer Analytic Hierarchy Process digunakan untuk menentukan peringkat atau mengurutkan informasi berdasarkan sejumlah kriteria. DS/AHP memanfaatkan Pairwise Comparison, Consistency Ratio, dan Dempster Rule's of Combination, yang digunakan untuk menghasilkan sistem informasi berupa urutan program studi sebagai bahan pertimbangan untuk pemilihan jurusan bagi calon mahasiswa. Sampel yang digunakan pada penelitian ini sebanyak 29 siswa lima fakultas di Universitas Diponegoro Semarang. Data yang digunakan adalah standar nilai minimum dari masing-masing fakultas dan nilai rata-rata rapor semester 1-5 mata pelajaran Matematika, Bahasa Indonesia, Bahasa Inggris, Biologi, Kimia, dan Fisika. Hasil dari penelitian ini adalah perangkat lunak pemilihan program studi calon mahasiswa yang memberikan nilai kepercayaan di setiap jurusan. Pengujian validitas nilai akurasi sistem dilakukan dengan membandingkan jurusan yang dipilih dengan hasil rekomendasi jurusan yang dihasilkan oleh sistem, keakurasian yang dihasilkan sebesar 79.33\%.
\end{abstract}

Keywords : Dempster shafer analytic hierarchy process; Rekomendasi jurusan; Standart nilai minimum; Nilai rata-rata rapor

\section{Pendahuluan}

Calon mahasiswa seringkali dihadapkan dengan pengambilan keputusan untuk menentukan beberapa pilihan jurusan di Perguruan Tinggi yang sesuai dengan minat dan bakatnya (Swastina, 2013). Permasalahan yang dihadapi oleh siswa yaitu memutuskan pilihan jurusan di perguruan tinggi yang sesuai dengan kemampuan yang dimiliki.

SNMPTN merupakan seleksi nasional untuk masuk Perguruan Tinggi berdasarkan dari prestasi akademik menggunakan nilai rapor dari semester satu sampai dengan semester lima bagi siswa Sekolah Menengah Atas (SMA) (penerimaan.undip.ac.id).

*) Penulis korespondensi: menur.wahyu.p@gmail.com
Adapun beberapa faktor yang menjadi acuan untuk memilih jurusan yang sesuai, yaitu dengan melihat kecenderungan nilai rapor selama duduk di bangku SMA, dan melihat jurusan yang diminati oleh calon mahasiswa.

Metode DS dapat digunakan untuk memberi alternatif ranking atau objek dan Ekstension Pairwise Comparrison. Penggunaan Dempster Shafer Analytic Hierarchy Process (DS/AHP) diterapkan untuk membangun bentuk fungsional dari bobot preferensi yang diberikan kepada kelompok Decision Alternatif (DA). Fungsi ini memungkinkan pemahaman tentang kelayakan nilai skala peringkat yang digunakan dalam metode DS/AHP, melalui evaluasi berbagai ketidakpastian yang dapat diekspresikan oleh 
pengambil keputusan (Beynon, 2002). Metode DS/AHP dapat memecahkan masalah secara langsung berdasarkan matriks keputusan yang lengkap (Hua et al., 2008).

Pada penelitian ini, penulis menggunakan metode DS/AHP yang digunakan untuk memberikan probabilitas beberapa kemungkinan dan urutan program studi dari beberapa kemungkinan sehingga para siswa dapat mengambil keputusan program studi mana yang sesuai dari hasil masukan yang diberikan oleh sistem.

\section{Kerangka Teori}

\subsection{Sistem Pendukung Keputusan}

Sistem pendukung keputusan merupakan sebuah sistem yang dapat memecahkan masalah dan mengkomunikasikan untuk masalah semi terstruktur dengan cara memberikan informasi ataupun usulan menuju pada keputusan tertentu (Hermawan, 2005). Sistem pendukung keputusan dimaksudkan agar dapat menjadi alat bantu bagi para pengambil keputusan untuk dapat memperluas kapabilitas seorang pengambil keputusan, namun tidak untuk menggantikan penilaian mereka. Karakteristik dan kapabilitas kunci dari sistem pendukung keputusan yaitu dukungan dalam pengambil keputusan, terutama pada situasi semi terstruktur dan tak terstruktur dengan menyertakan penilaian manusia dan informasi terkomputerisasi. Sistem pendukung keputusan ditujukan untuk keputusan-keputusan yang memerlukan penilaian atau pada keputusankeputusan yang sama sekali tidak dapat didukung oleh algoritma (Turban et al., 2005).

\subsection{Dempster Shafer Analytic Hierarchy Process}

DS/AHP diperkenalkan oleh Beynon, Curry, dan Morgan di tahun 2000 (Beynon, 2001). DS/AHP dikembangkan kembali oleh Beynon, Cosker dan Marshall di tahun 2002 yang merupakan suatu teknik yang mendukung proses pengambilan keputusan (Beynon, 2008).

Metode DS/AHP digunakan untuk memunculkan nilai plausibillity atau nilai kemungkinan yang didalamnya terdapat ketidakpastian (uncertainty) yang ada disetiap alternatif yang tidak ada pada metode AHP. Nilai plausibillity dianggap perlu dimasukkan karena dalam memberikan bobot baik untuk alternatif maupun kriteria, tentunya harus didasarkan pada data atau informasi maupun pengetahuan yang memadai (Beynon, 2000).

Metode DS/AHP digunakan dalam membantu pengambilan keputusan menentukan peringkat atau mengurutkan informasi berdasarkan sejumlah kriteria (Beynon, 2002). Hasil dari analisis DS/AHP adalah tingkat preferensi pada kelompok DA atau yang biasa disebut dengan Body Of Evidence (BOE) (Beynon, 2005).

\subsection{Prosedur Pengambilan Keputusan Dengan DS/AHP}

Adapun tahapan dari metode DS/AHP yaitu Analisa Kriteria dan Alternatif penentuan Jurusan dengan DS/AHP (Beynon, 2008):

1. Menentukan bobot masing-masing kriteria

2. Penentuan grup DA di masing-masing kriteria

3. Analisa hirarki keputusan penentuan jurusan

4. Proses Pairwise Comparison dimana dari hasil Pairwaise Comparison ditabulasi dalam Comparison Matriks

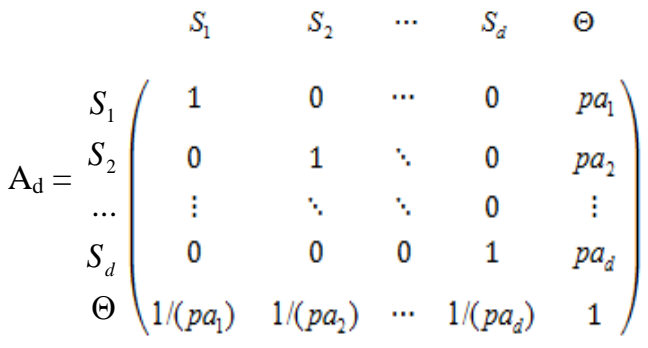

Keterangan :

$\begin{aligned} \mathrm{A}_{\mathrm{d}} & \text { Matriks perbandingan pada } \\ & \text { Group Decision Alternatif } \\ \mathrm{S}_{1}, \mathrm{~S}_{2}, \ldots . \mathrm{S}_{\mathrm{d}}= & \text { Group Decision Alternatif (DA) } \\ \Theta & \text { FOD atau Environtment yang } \\ & \text { merupakan DA yang berisi } \\ & \text { seluruh alternatif } \\ = & \text { Bobot untuk } \mathrm{S}_{1}, \mathrm{~S}_{2}, \ldots . . \mathrm{S}_{\mathrm{d}} \\ & \text { terhadap hasil dari Pairwise } \\ & \text { Comparison } \mathrm{S}_{1}, \mathrm{~S}_{2}, \quad \ldots . . . \mathrm{S}_{\mathrm{d}} \\ & \text { terhadap } \Theta \text { (hasil dari Pairwise } \\ & \text { Comparison) } \\ = & \text { Bobot kriteria } \\ = & \text { Jumlah DA }\end{aligned}$

Bobot setiap DA tercermin dari nilai Priority Vector, yang dikenal juga dengan sebutan Mass Value, $\mathrm{m}\left(\mathrm{s}_{\mathrm{i}}\right)$. Nilai $\mathrm{m}\left(\mathrm{s}_{\mathrm{i}}\right)$ antara 0 dan 1 , sedangkan total $\mathrm{m}\left(\mathrm{s}_{\mathrm{i}}\right)$ dalam suatu jenis kriteria adalah satu, $\sum \mathrm{m}(\mathrm{si})=1$. Pembobotan dilakukan untuk setiap kriteria.

5. Terakhir adalah proses Dempster's Rule of Combination. Untuk menghitung bobot untuk setiap alternatif, dengan menggunakan rumus Dempster's Rule of Combination. 


$$
\left[m_{1} \oplus m_{2}\right](y)=\frac{\sum_{s_{1 n^{n}} s_{2}=[y]} m_{1}\left(s_{1}\right) m_{2}\left(s_{2}\right)}{1-\sum_{s_{1} n_{2}}=\left[\rho_{1} m_{1}\left(s_{1}\right) m_{2}\left(s_{2}\right)\right.}
$$

Keterangan :

$$
\begin{array}{ll}
{\left[m_{1} \oplus m_{2}\right](y)} & =\text { mass function dari evidence }(\mathrm{y}) \\
\oplus & =\text { operator direct sum } \\
m_{1}\left(s_{1}\right) & =\text { mass value dari evidence }\left(s_{1}\right) \\
m_{2}\left(s_{2}\right) & =\text { mass value dari evidence }\left(s_{2}\right)
\end{array}
$$

Kombinasi dari $m_{1}$ dan $m_{2}$ adalah $m_{3}$ yang dirumuskan dengan persamaan pada 2.3

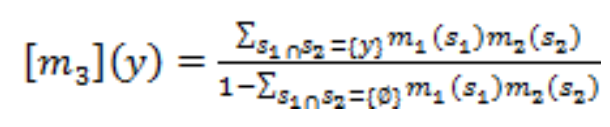

Keterangan :

$$
\begin{array}{ll}
{\left[m_{3}\right](y)} & =\text { mass function dari evidence }(\mathrm{y}) \\
m_{1}\left(s_{1}\right) & =\text { mass value dari evidence }\left(s_{1}\right) \\
m_{2}\left(s_{2}\right) & =\text { mass value dari evidence }\left(s_{2}\right)
\end{array}
$$

Persamaan DS/AHP jika terjadi munculnya mass function $(\mathrm{m})$ baru (2.4)

$$
\left[m_{n}\right](y)=\frac{\sum_{s_{1 n} S_{2}=[y]} m_{n}\left(s_{1}\right) m_{n}\left(s_{2}\right)}{1-\sum_{\left.s_{1 n} s_{2}=[\varnothing]\right]_{n}} m_{n}\left(s_{1}\right) m_{n}\left(s_{2}\right)}
$$

Keterangan :

$$
\begin{array}{ll}
{\left[m_{n}\right](y)} & =\text { mass function dari evidence }(\mathrm{y}) \\
m_{n}\left(s_{1}\right) & =\text { mass value dari evidence }\left(s_{1}\right) \\
m_{n}\left(s_{2}\right) & =\text { mass value dari evidence }\left(s_{2}\right)
\end{array}
$$

\begin{tabular}{|c|c|c|}
\hline $\begin{array}{c}\text { Nilai } \\
\text { Kepentingan }\end{array}$ & Definisi & Penjelasan \\
\hline 1 & Sama Penting & $\begin{array}{l}\text { Kedua elemen sama } \\
\text { pentingnya }\end{array}$ \\
\hline 3 & $\begin{array}{l}\text { Elemen satu sedikit } \\
\text { lebih penting }\end{array}$ & $\begin{array}{c}\text { Pengalaman dan } \\
\text { penilaian sedikit } \\
\text { mendukung satu elemen } \\
\text { atas lainnya }\end{array}$ \\
\hline 5 & $\begin{array}{c}\text { Elemen satu penting } \\
\text { atau kuat pentingnya } \\
\text { dari elemen lainnya }\end{array}$ & $\begin{array}{c}\text { Pengalaman dan } \\
\text { penilaian sangat } \\
\text { mendukung satu elemen } \\
\text { atas lainnya }\end{array}$ \\
\hline 7 & Sangat penting & $\begin{array}{c}\text { Satu elemen sangat } \\
\text { disukai dan } \\
\text { dominannya } \\
\text { ditunjukkan dalam } \\
\text { praktek }\end{array}$ \\
\hline 9 & Mutlak lebih penting & $\begin{array}{l}\text { Bukti mendukung satu } \\
\text { elemen yang satu atas } \\
\text { yang lain memiliki } \\
\text { tingkat penegasan } \\
\text { tertinggi yang mungkin } \\
\text { menguatkan }\end{array}$ \\
\hline $2,4,6,8$ & $\begin{array}{c}\text { Nilai-nilai diantara dua } \\
\text { pertimbangan yang } \\
\text { berdekatan }\end{array}$ & $\begin{array}{c}\text { Kompromi diperlukan } \\
\text { antara dua } \\
\text { pertimbangan }\end{array}$ \\
\hline Kebalikan & \multirow{2}{*}{\multicolumn{2}{|c|}{$\begin{array}{c}\text { Jika untuk aktivitas } i \text { mendapat satu angka bila } \\
\text { dibandingkan dengan suatu aktivitas } j, \text { maka } j \\
\text { mempunyai nilai kebalikannya bila dibandingkan } \\
\text { dengan aktivitas } i \\
\text { Rasio yang timbul dari konsistensi penilaian }\end{array}$}} \\
\hline Rasional & & \\
\hline
\end{tabular}

\subsection{Metode Perbandingan Berpasangan}

Untuk dapat membuat matriks perbandingan berpasangan, maka terlebih dahulu menentukan nilai bobot di setiap kriteria (Marimin, 2004). Matriks perbandingan berpasangan ditunjukan pada Tabel 1 .

Tabel 1. Matriks perbandingan berpasangan

\begin{tabular}{|c|c|c|c|c|}
\hline & $\mathrm{A}_{1}$ & $\mathrm{~A}_{2}$ & $\ldots \ldots$ & $\mathrm{A}_{\mathrm{n}}$ \\
\hline $\mathrm{A}_{1}$ & 1 & & $\ldots \ldots$ & \\
\hline $\mathrm{A}_{2}$ & & 1 & $\ldots \ldots$ & \\
\hline$\ldots$. & $\ldots \ldots$ & $\ldots \ldots$ & $\ldots \ldots$ & $\ldots \ldots$ \\
\hline $\mathrm{A}_{\mathrm{n}}$ & & & $\ldots \ldots$ & 1 \\
\hline
\end{tabular}

Keterangan

$$
\mathrm{A}_{1}, \mathrm{~A}_{2}, \mathrm{~A}_{\mathrm{n}} \quad \text { : Perbandingan antar kriteria }
$$

Skala perbandingan berpasangan ditunjukkan pada Tabel 2 (Kousalya et al., 2012).
Tabel 2 Tingkat kepentingan relatif

\subsection{Bobot Kriteria}

Prosedur untuk mendapatkan bobot kriteria adalah (Marimin, 2004) :

1. Buat matriks perbandingan berpasangan

2. Kuadratkan matriks tersebut

3. Jumlahkan nilai dari setiap baris dan hasil penjumlahan tersebut dijumlahkan kembali.

4. lakukan normalisasi dengan cara membagi dengan hasil penjumlahan terakhir yang akan menghasilkan nilai Eigenvector (bobot setiap kriteria).

\subsection{Rasio Konsistensi}

Prinsip kerja dari Rasio Konsistensi adalah untuk menetukan bobot yang sesuai dari kriteria (Goshal, 2011) :

1. Hitung jumlah matrik tertimbang (weighted sum vector)

2. Bagi semua elemen dari jumlah matriks tertimbang dengan nilai Priority Vector

3. Hitung nilai rata-rata untuk mendapatkan nilai $\lambda \max$ dengan menjumlahkan nilai Vector Consistency dan membaginya dengan jumlah faktor yang sedang dibandingkan.

4. Rumus untuk menghitung rasio konsistensi :

$$
\mathrm{CR}=\frac{\mathrm{CI}}{\mathrm{RI}}
$$

Keterangan :

Consistency Ratio $(\mathrm{CR}) \quad=$ Apabila nilai $\mathrm{CR} \leq 0,1$, maka matriks perbandingan berpasangan dapat diterima, dan apabila nilai $\mathrm{CR}>0,1$, maka perhitungan perbandingan berpasangan diulang kembali hingga menghasilkan matriks yang konsisten. 
CI $=$ Consistency Index

RI = Random Consistency Index ditunjukkan pada Tabel 3

5. Rumus dari Consistency Index yaitu :

$$
\mathrm{CI}=\frac{2 \max -\mathrm{n}}{\mathrm{n}-1}
$$

Keterangan :

$\lambda \max =$ eigenvalue tertinggi dari matriks

$\mathrm{n} \quad=$ Banyaknya elemen / Ukuran matriks

Tabel 3. Random Consistency Index (RI)

(Franek et al., 2014)

\begin{tabular}{cc}
\hline $\mathbf{N}$ & $\mathbf{R I}$ \\
\hline 1 & 0 \\
2 & 0 \\
3 & 0.58 \\
4 & 0.90 \\
5 & 1.12 \\
6 & 1.24 \\
7 & 1.32 \\
8 & 1.41 \\
9 & 1.45 \\
10 & 1.49 \\
11 & 1.51 \\
\hline
\end{tabular}

\section{Metodologi}

\subsection{Prosedur Penelitian}

Penelitian ini dilakukan dengan beberapa tahapan. Tahapan dari metode ini yaitu tahap identifikasi masalah, studi pustaka, pengumpulan data, pengolahan data, tahap perhitungan dan penentuan jurusan menggunakan metode DS/AHP, tahap perancangan sistem, tahap implementasi sistem, tahap pengujian sistem, dan tahap penyusunan laporan yang ditunjukkan pada Gambar 1 .

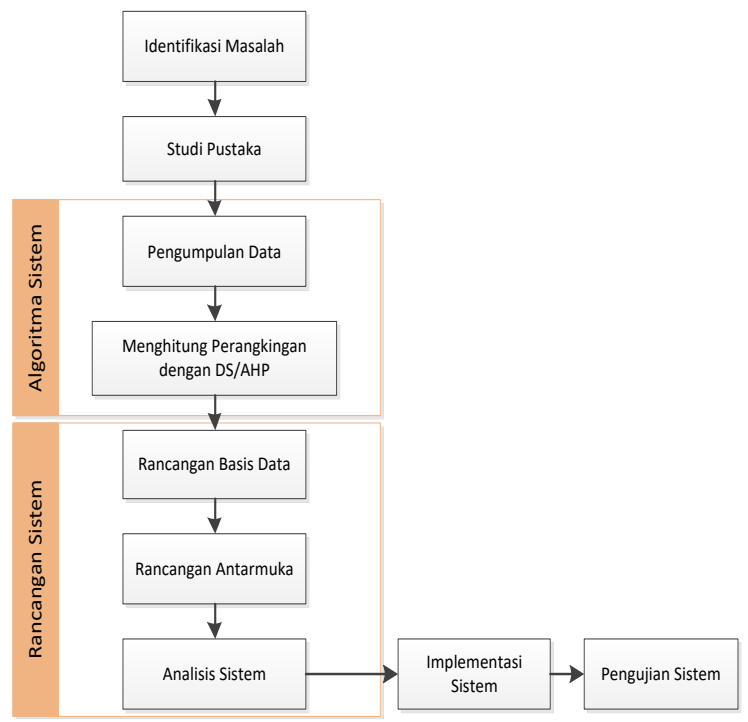

Gambar 1. Prosedur Penelitian

\subsection{Algoritma Sistem}

3.2.1 Pengumpulan data

A. Pengelompokan Jurusan

Passing Grade merupakan batasan nilai yang digunakan sebagai acuan pada saat pemilihan jurusan di suatu universitas. Nilai Passing Grade yang tinggi membuktikan bahwa jurusan tersebut banyak diminati oleh calon mahasiswa. Pada penelitian ini, jurusan ditentukan dari nilai Passing Grade tertinggi yang dimiliki oleh setiap jurusan. Universitas Diponegoro memiliki 11 fakultas dan 47 jurusan. Data Passing Grade diambil dari data e-sbmptn pada tahun 2015 dan syarat khusus program studi diambil dari informasi penerimaan undip. Pada penelitian ini difokuskan pada jurusan IPA favorit yang mewakili 11 fakultas, sehingga jurusan yang digunakan dalam kasus ini ditunjukkan pada Tabel 4.

Tabel 4. Daftar Jurusan

\begin{tabular}{ccc}
\hline No & Jurusan & Passing Grade \\
\hline 1 & Kesehatan Masyarakat & $34.6 \%$ \\
2 & Kedokteran Umum & $51.2 \%$ \\
3 & Ilmu Kelautan & $29.2 \%$ \\
4 & Sistem Komputer & $40.8 \%$ \\
5 & Peternakan & $22.8 \%$ \\
\hline
\end{tabular}

Model hirarki keputusan dibuat untuk mempermudah dalam pengambilan keputusan pada penentuan jurusan yang ditunjukkan pada Gambar 2.

\section{B. Standart Nilai Minimum}

Pada penelitian ini nilai siswa di setiap mata pelajaran akan diberikan bobot sesuai dengan standart nilai minimum yang ada di setiap jurusan. Standart nilai minimum ditunjukkan Tabel 5.

Tabel 5. Standart Nilai Minimum

\begin{tabular}{ccccccc}
\hline Jurusan & Mat & B.Ind & B.Ing & Bio & Kim & Fis \\
\hline $\begin{array}{c}\text { Kesehatan } \\
\text { Masyarakat }\end{array}$ & 75 & 85 & 80 & 75 & 75 & 75 \\
$\begin{array}{c}\text { Kedokteran } \\
\text { Umum }\end{array}$ & 75 & 85 & 80 & 85 & 80 & 80 \\
$\begin{array}{c}\text { Ilmu } \\
\text { Kelautan }\end{array}$ & 80 & 80 & 80 & 75 & 75 & 85 \\
$\begin{array}{c}\text { Sistem } \\
\text { Komputer }\end{array}$ & 80 & 70 & 80 & 70 & 70 & 75 \\
$\begin{array}{c}\text { Peternakan } \\
\text { Nomen }\end{array}$ & 70 & 75 & 75 & 85 & 75 & 70 \\
\hline
\end{tabular}

\section{Penentuan Skala Pembobotan}

Pemberian skala bobot pada penelitian ini dilakukan dua kali yaitu skala pembobotan pada nilai rapor di setiap mata pelajaran per siswa untuk menentukan bobot di masing-masing kriteria dan skala pembobotan pada nilai rapor di setiap mata pelajaran per siswa untuk menentukan Grup Decision Alternatif di masing-masing kriteria. Skala pembobotan tersebut di tunjukkan pada Tabel 6 dan Tabel 7. 
Tabel 6. Skala pembobotan di masing-masing kriteria

\begin{tabular}{cl}
\hline Bobot & \multicolumn{1}{c}{ Keterangan } \\
\hline 1 & Sangat Rendah \\
2 & Rendah \\
3 & Agak Rendah \\
4 & Agak Tinggi \\
5 & Tinggi \\
6 & Sangat Tinggi \\
\hline
\end{tabular}

Tabel 7. Skala pembobotan pada Grup Decision Alternatif

\begin{tabular}{ccc} 
BOBOT & SKALA $(+)$ & SKALA (-) \\
\hline 1 & $26-30$ & $(-11)-(-15)$ \\
2 & $21-25.9$ & $(-6.0)-(10.9)$ \\
3 & $16-20.9$ & $(-0)-(-5.9)$ \\
4 & $11.0-15.9$ & \\
5 & $6.0-10.9$ & \\
6 & $0-5.9$ & \\
\hline
\end{tabular}

\section{Menghitung perangkingan dengan DS/AHP}

Metode DS/AHP digunakan untuk membantu pengambilan keputusan menentukan peringkat atau mengurutkan informasi pada penentuan pemilihan program studi calon mahasiswa. Beberapa tahapan untuk melakukan perangkingan dapat dilihat pada Gambar 3.

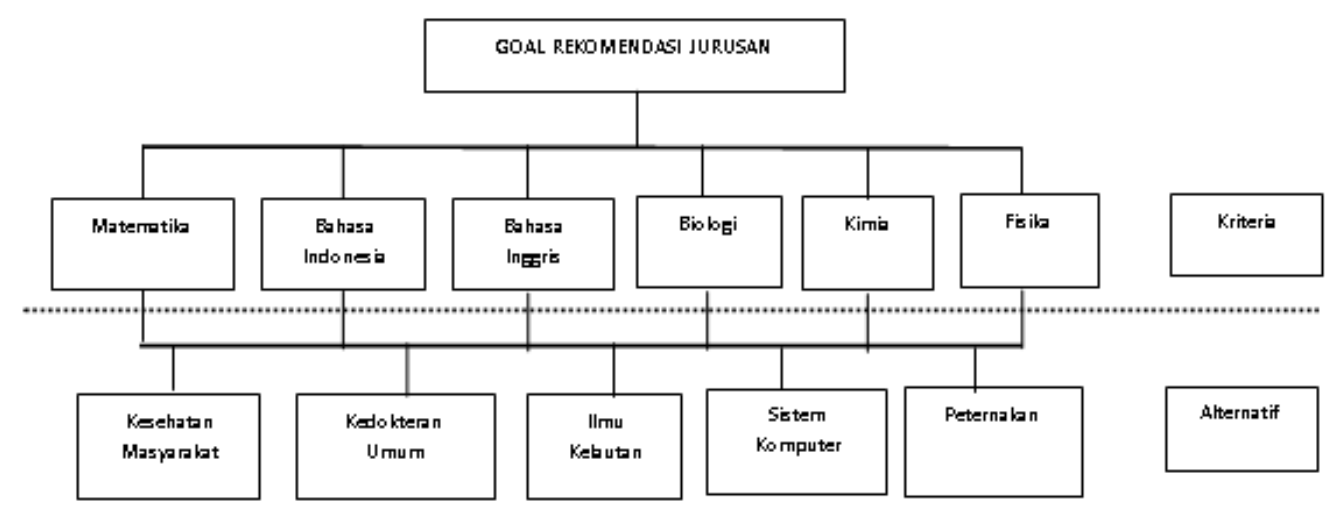

Gambar 2. Model hirarki keputusan

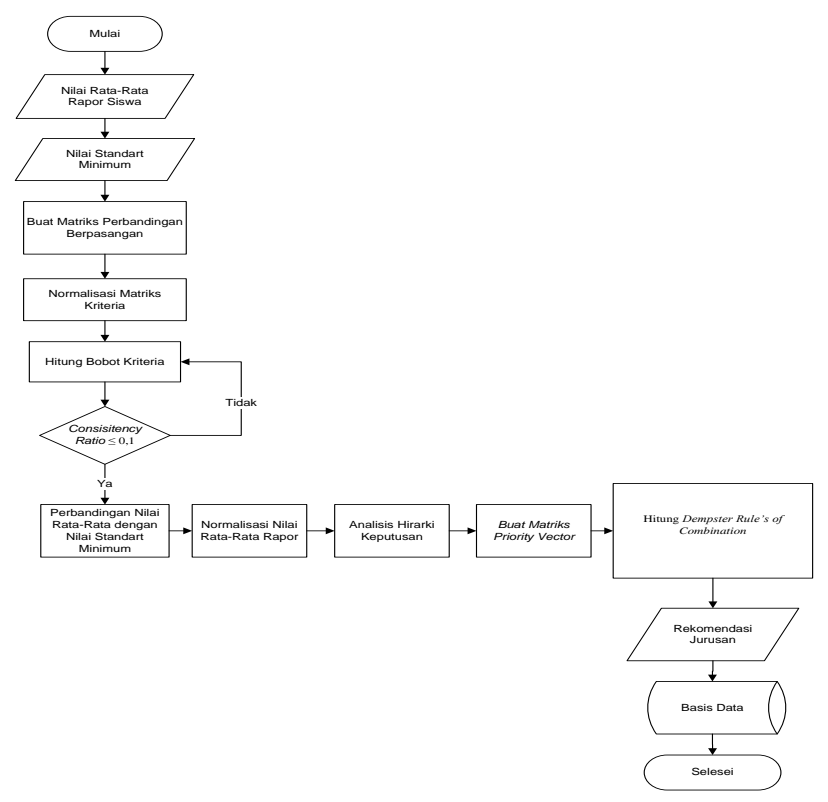

Gambar 3. Flowchart tahapan proses DS/AHP 


\section{Hasil dan Pembahasan}

\subsection{Kerangka Sistem}

Kerangka sistem dengan metode DS/AHP di tunjukkan pada Gambar 4.

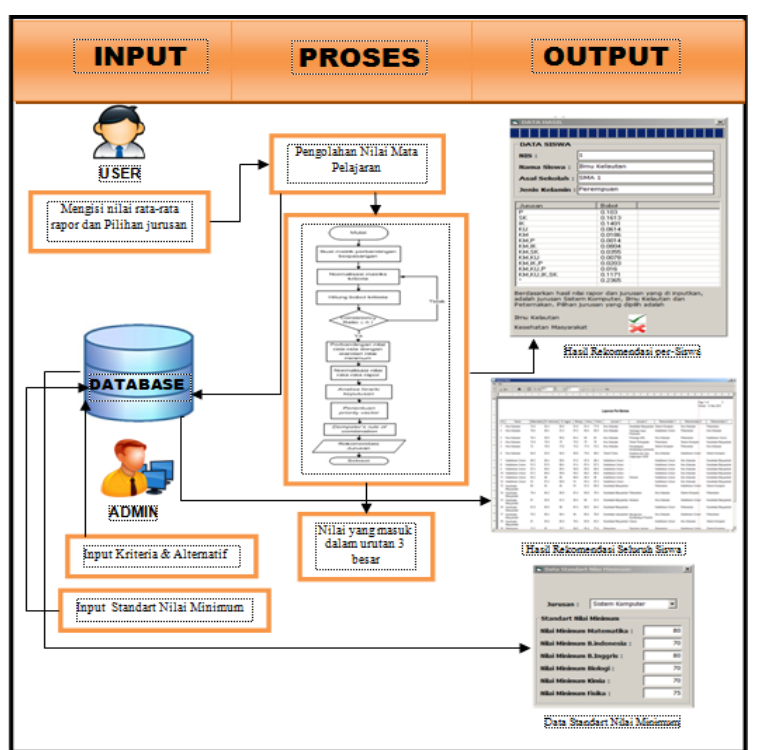

Gambar 4 Kerangka sistem dengan metode DS/AHP

\subsection{Perhitungan Penentuan Jurusan Menggunakan Metode Dempster Shafer Analytic Hierarchy Process}

\subsubsection{Analisa Kriteria Penentuan Jurusan}

Penentuan kriteria merupakan langkah awal dalam penggunaan metode DS/AHP. Terdapat kriteria untuk menentukan jurusan yang digunakan dalam sistem ini yaitu nilai rata-rata rapor. Nilai ratarata rapor yang digunakan adalah nilai rapor pada semester 1-5 yang meliputi Nilai Rata-Rata Matematika, Nilai Rata-Rata Bahasa Indonesia, Nilai Rata-Rata Bahasa inggris, Nilai Rata-Rata Biologi, Nilai Rata-Rata Kimia, Nilai Rata-Rata Fisika.

\subsubsection{Penentuan Bobot Kriteria}

Matriks bobot nilai kepentingan kriteria ditentukan dari perbandingan setiap mata pelajaran. Untuk dapat menentukan prioritas antar kriteria, maka nilai rata-rata rapor di setiap kriteria diberi bobot terlebih dahulu. Adapun perhitungan sample data satu pada Jurusan Ilmu Kelautan dengan nilai rata-rata rapor matematika $=75.6$, nilai rata-rata rapor Bahasa Indonesia $=83.4$, nilai rata-rata rapor Bahasa Inggris $=83.6$, nilai rata-rata rapor biologi $=$ 81.6 , nilai rata-rata rapor kimia $=81.4$, dan nilai ratarata rapor fisika $=77.8$. Berikut langkah-langkah untuk menentukan bobot kriteria seperti yang dilakukan pada metode AHP.

1. Urutkan nilai rapor di enam mata pelajaran dari nilai terkecil ke nilai terbesar seperti yang ditunjukkan pada Tabel 8.
Tabel 8. Pemberian bobot nilai rata-rata

\begin{tabular}{ccc}
\hline Mata Pelajaran & Nilai & Bobot \\
\hline Matematika & 75,6 & 1 \\
Bhs Indonesia & 83,4 & 5 \\
Bhs Inggris & 83,6 & 6 \\
Biologi & 81,6 & 4 \\
Kimia & 81,4 & 3 \\
Fisika & 77,8 & 2 \\
\hline
\end{tabular}

2. Ubah kedalam bentuk matriks perbandingan berpasangan. Sehingga matriks perbandingan berpasangan ditunjukkan pada Tabel 9.

Tabel 9. Matriks perbandingan berpasangan

\begin{tabular}{ccccccc}
\hline & $\begin{array}{c}\text { Mat } \\
(\mathbf{1})\end{array}$ & $\begin{array}{c}\text { B.Ind } \\
(\mathbf{5})\end{array}$ & $\begin{array}{c}\text { B.Ing } \\
(\mathbf{6})\end{array}$ & $\begin{array}{c}\text { Bio } \\
(\mathbf{4})\end{array}$ & $\begin{array}{c}\text { Kim } \\
(\mathbf{3})\end{array}$ & $\begin{array}{c}\text { Fis } \\
(\mathbf{2})\end{array}$ \\
\hline Mat(1) & 1,00 & 0,14 & 0,11 & 0,20 & 0,33 & 0,50 \\
& 7,00 & 1,00 & 0,50 & 2,00 & 3,00 & 5,00 \\
B.Ind(5) & 9,00 & 2,00 & 1,00 & 3,00 & 5,00 & 7,00 \\
B.Ing (6) & 5,00 & 0,50 & 0,33 & 1,00 & 2,00 & 3,00 \\
Bio (4) & 3,00 & 0,33 & 0,20 & 0,50 & 1,00 & 2,00 \\
Kim (3) & 2,00 & 0,20 & 0,14 & 0,33 & 0,50 & 1,00 \\
Fis (2) & 27,00 & 4,17 & 2,28 & 7,03 & 11,83 & 18,50 \\
Jumlah & & & & & & \\
\hline
\end{tabular}

3. Buat matriks normalisasi untuk mendapatkan bobot seperti pada Tabel 10 .

Tabel 10 Matriks normalisasi

\begin{tabular}{|c|c|c|c|c|c|c|c|c|}
\hline Kriteria & Mat & B.Ind & B.Ing & Bio & Kim & Fis & $\begin{array}{l}\text { Jmlh } \\
\text { Baris }\end{array}$ & $\begin{array}{c}\text { Bobot } \\
\text { Kriteria }\end{array}$ \\
\hline Mat (1) & 6,00 & 0,81 & 0,49 & 1,35 & 2,30 & 3,75 & 14,72 & 0,03 \\
\hline $\begin{array}{l}\text { B.Ind } \\
\text { (5) }\end{array}$ & 47,50 & 6,00 & 3,75 & 10,06 & 17,33 & 29,00 & 113,65 & 0,25 \\
\hline $\begin{array}{c}\text { B.Ing } \\
\text { (6) }\end{array}$ & 76,00 & 9,85 & 6,00 & 16,63 & 28,50 & 47,50 & 184,48 & 0,41 \\
\hline $\begin{array}{l}\text { Bio } \\
\text { (4) }\end{array}$ & 28,50 & 3,64 & 2,30 & 6,00 & 10,33 & 17,33 & 68,11 & 0,15 \\
\hline$\underset{(3)}{\mathbf{K i m}}$ & 16,63 & 2,14 & 1,35 & 3,53 & 6,00 & 10,06 & 39,73 & 0,08 \\
\hline $\begin{array}{l}\text { Fis } \\
(2) \\
\end{array}$ & 9,85 & 1,30 & 0,81 & 2,14 & 3,64 & 6,00 & 23,76 & 0,05 \\
\hline & & & & & & & 444,48 & 1,00 \\
\hline & & & & & \multicolumn{2}{|c|}{$\lambda$ max } & 6.0582 & \\
\hline & & & & & \multicolumn{2}{|c|}{$\mathrm{CI}$} & 0.0116 & \\
\hline & & & & & \multicolumn{2}{|c|}{ CR } & 0.0094 & \\
\hline
\end{tabular}

4. Karena nilai $\mathrm{CR} \leq 0.1$, maka matriks tersebut telah konsisten. sehingga di dapatkan bobot akhir seperti yang ditunjukkan pada Tabel 11.

Tabel 11. Bobot kriteria

\begin{tabular}{ccc} 
No & Kriteria & Bobot \\
\hline 1 & Matematika & 0.0331 \\
2 & Bahasa Indonesia & 0.2557 \\
3 & Bahasa Inggris & 0.4151 \\
4 & Biologi & 0.1532 \\
5 & Kimia & 0.0894 \\
6 & Fisika & 0.0535 \\
\hline
\end{tabular}




\subsubsection{Penentuan Grup Decision Alternatif di masing- masing kriteria \\ Untuk suatu kriteria maka ditentukan alternatif} yang terdiri dari satu atau lebih alternatif, termasuk Decision Alternatif yang berisi seluruh alternatif $(\Theta)$ yang ditunjukkan pada Tabel 12 .

Tabel 12. Decision alternatif keputusan

\begin{tabular}{cl}
\hline No & \multicolumn{1}{c}{ Nama Jurusan } \\
\hline 1 & Kesehatan Masyarakat \\
2 & Kedokteran Umum \\
3 & Ilmu Kelautan \\
4 & Sistem Komputer \\
5 & Peternakan \\
\hline
\end{tabular}

Adapun langkah-langkah dalam menentukan Decision Alternatif pada kasus pemilihan jurusan.

A. Kelompokkan nilai per siswa kedalam nilai standart minimum seperti yang ditunjukkan pada Tabel 13.

B. Setelah dilakukan pengelompokkan, maka selanjutnya adalah menentukan Decision Alternatif dengan cara menentukan bobot nilai calon mahasiswa berdasarkan nilai minimum perjurusan sesuai dengan skala pembobotan pada Grup Decision Alternatif yang ditunjukkan pada Tabel 7. Untuk mendapatkan bobot nilai per jurusan, maka selanjutnya adalah normalisasi bobot tersebut dengan cara membagi dengan nilai terkecil.

Tabel 13 Nilai standart minimum dan nilai siswa

\begin{tabular}{ccccccc} 
Jurusan & Mat & B.Ind & B.Ing & Bio & Kim & Fis \\
\hline $\begin{array}{c}\text { Kesehatan } \\
\text { Masyarakat }\end{array}$ & 75 & 85 & 80 & 75 & 75 & 75 \\
$\begin{array}{c}\text { Kedokteran } \\
\text { Umum }\end{array}$ & 75 & 85 & 80 & 85 & 80 & 80 \\
$\begin{array}{c}\text { Ilmu } \\
\text { Kelautan }\end{array}$ & 80 & 80 & 80 & 75 & 75 & 85 \\
$\begin{array}{c}\text { Sistem } \\
\text { Komputer }\end{array}$ & 80 & 70 & 80 & 70 & 70 & 75 \\
Peternakan & 70 & 75 & 75 & 85 & 75 & 70 \\
Nilai & 75,6 & 83,4 & 83,6 & 81,6 & 81,4 & 77,8 \\
\hline
\end{tabular}

C. Langkah selanjutnya adalah membuat matriks perbandingan berpasangan antar alternatif di setiap kriteria. Nilai $\Theta$ merupakan nilai keseluruhan dari setiap alternatif.

1. Nilai Matematika

Untuk kriteria Matematika, digunakan dua DA,

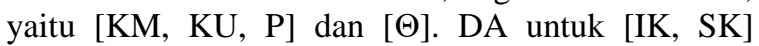
diwakilkan oleh $[\Theta]$ yang ditunjukkan pada Tabel 14 .

Tabel 14 Hasil alternatif nilai matematika

\begin{tabular}{cc} 
Alternatif & $\boldsymbol{\Theta}$ \\
\hline KM,KU,P & 2,00 \\
IK,SK & 1,00 \\
\hline
\end{tabular}

2. Nilai Bahasa Indonesia

Untuk kriteria Bahasa Indonesia, digunakan empat DA, yaitu [IK], [SK], [P] dan $[\Theta]$. DA untuk $[\mathrm{KM}, \mathrm{KU}]$ diwakilkan oleh $[\Theta]$ yang ditunjukkan pada Tabel 15.

Tabel 15 Hasil alternatif nilai bahasa indonesia

\begin{tabular}{cc} 
Alternatif & $\boldsymbol{\Theta}$ \\
\hline KM,KU & 1,00 \\
IK & 2,00 \\
SK & 1,33 \\
P & 1,66 \\
\hline
\end{tabular}

3. Nilai Bahasa Inggris

Untuk kriteria Bahasa Inggris, digunakan dua

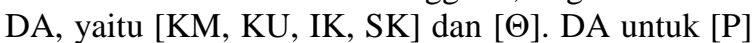
diwakilkan oleh $[\Theta]$ yang ditunjukkan pada Tabel 16 .

Tabel 16 Hasil alternatif nilai bahasa inggris

\begin{tabular}{cc} 
Alternatif & $\boldsymbol{\Theta}$ \\
\hline $\mathrm{KM}, \mathrm{KU}, \mathrm{IK}, \mathrm{SK}$ & 1,20 \\
$\mathrm{P}$ & 1,00 \\
\hline
\end{tabular}

4. Nilai Biologi

Untuk kriteria Biologi, digunakan tiga DA, yaitu $[\mathrm{KM}, \mathrm{IK}],[\mathrm{SK}]$ dan $[\Theta]$. DA untuk [KU, P] diwakilkan oleh $[\Theta]$ yang ditunjukkan pada Tabel 17.

Tabel 17 Hasil alternatif nilai biologi

\begin{tabular}{cc} 
Alternatif & $\boldsymbol{\Theta}$ \\
\hline KM,IK & 1,66 \\
KU,P & 1,00 \\
SK & 1,33 \\
\hline
\end{tabular}

5. Nilai Kimia

Untuk kriteria Kimia, digunakan tiga DA, yaitu $[\mathrm{KM}, \mathrm{IK}, \mathrm{P}],[\mathrm{KU}]$ dan $[\Theta]$. DA untuk [SK] diwakilkan oleh $[\Theta]$ yang ditunjukkan pada Tabel 18 .

Tabel 18 Hasil alternatif nilai kimia

\begin{tabular}{cc}
\hline Alternatif & $\boldsymbol{\Theta}$ \\
\hline KM,IK,P & 1,25 \\
KU & 1,50 \\
SK & 1,00 \\
\hline
\end{tabular}

6. Nilai Fisika

Untuk kriteria Fisika, digunakan empat DA, yaitu

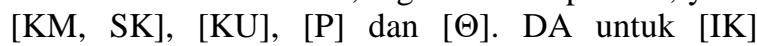
diwakilkan oleh $[\Theta]$ yang ditunjukkan pada Tabel 19. 
Tabel 19 Hasil Alternatif Nilai Fisika

\begin{tabular}{cc} 
Alternatif & $\boldsymbol{\Theta}$ \\
\hline KM,SK & 3,00 \\
KU & 1,50 \\
IK & 1,00 \\
P & 2,50 \\
\hline
\end{tabular}

\subsubsection{Analisa Hirarki Keputusan Penentuan Jurusan}

Setelah dilakukan DA untuk keseluruhan Kriteria, langkah selanjutnya adalah membuat hirarki keputusan. Pembuatan hirarki keputusan penentuan jurusan bertujuan untuk mempermudah proses selanjutnya setelah mengetahui Group Decision Alternatif untuk masing-masing kriteria. Tabel hirarki keputusan penentuan jurusan yang ditunjukkan pada Gambar 5.

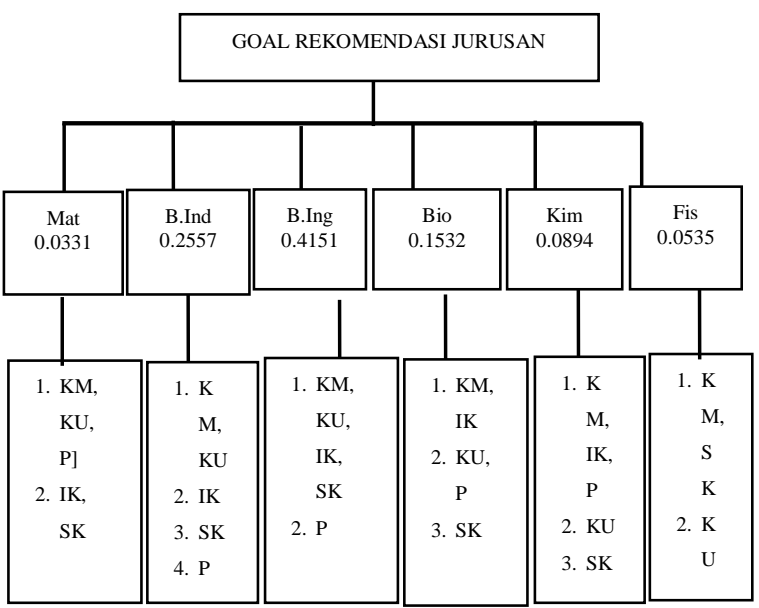

Gambar 5. Hirarki keputusan

\subsubsection{Proses Comparison Matriks}

Pada kriteria pertama, maka akan ditentukan bobot masing-masing DA dengan melakukan Pairwaise Comparison antara masing-masing DA yang berisi seluruh alternatif $(\Theta),(\Theta)$ atau Frame Of Discrement (FOD) yang merupakan semesta pembicaraan dari sekumpulan hipotesis sehingga sering disebut dengan Environtment. Setelah melakukan tahapan Pairwaise Comparison, maka hasil dari Pairwaise Comparison tersebut ditabulasi dalam comparison matriks.

Adapun langkah-langkah untuk mendapatkan nilai Priority Vector pada Kriteria Matematika

1. Berikut adalah Comparison Matriks pada kriteria matematika yang ditunjukkan pada Tabel 20.

Tabel 20. Comparison matriks pada kriteria matematika

\begin{tabular}{cccc} 
& KM, KU, P & $\boldsymbol{\Theta}$ & PV \\
\hline KM, KU, P & 1,00 & 0,06 & 0,06 \\
$\boldsymbol{\Theta}$ & 15,08 & 1,00 & 0,93 \\
Jumlah & 16,08 & 1,06 & 1,00 \\
\hline
\end{tabular}

2. Kuadratkan kembali matriks yang ditunjukkan pada Tabel 20, sehingga hasil dari pengkuadratan dapat dilihat pada Tabel 21.

Tabel 21. Kuadrat Matriks

\begin{tabular}{ccc}
\hline & $\mathbf{K M}, \mathbf{K U}, \mathbf{P}$ & $\boldsymbol{\Theta}$ \\
\hline $\mathbf{K M}, \mathbf{K U}, \mathbf{P}$ & 2,00 & 0,13 \\
$\boldsymbol{\Theta}$ & 30,17 & 2,00 \\
\hline
\end{tabular}

3. Normalisasi hasil kuadrat matriks dengan cara menjumlahkan setiap baris, dan hasil penjumlahan tersebut dijumlahkan kembali. Matriks normalisasi dapat dilihat pada Tabel 22

Tabel 22. Matriks Normalisasi

\begin{tabular}{ccccc}
\hline & KM, KU, $\mathbf{P}$ & $\boldsymbol{\Theta}$ & $\begin{array}{c}\text { Jumlah } \\
\text { Baris }\end{array}$ & PV \\
\hline KM, KU, $\mathbf{P}$ & 2,00 & 0,13 & 2,13 & 0,06 \\
$\quad \boldsymbol{\Theta}$ & 30,17 & 2,00 & 32,17 & 0,93 \\
Jumlah & & & 34,30 & 1,00 \\
\hline
\end{tabular}

4. Selanjutnya untuk mendapatkan nilai Priority Vector, maka normalisasi dengan cara membagi hasil penjumlahan setiap baris dengan hasil penjumlahan terakhir.

$$
\begin{aligned}
& \frac{2,13}{34,30}=0,06 \\
& \frac{32,17}{34,30}=0,93
\end{aligned}
$$

Hal yang sama pada perhitungan Matematika dilakukan untuk mendapatkan nilai Priority Vector pada kriteria yang lain. Nilai Priority Vector pada kriteria B.Indonesia, B.Inggris, Biologi, Kimia, dan Fisika di tunjukkan pada Tabel 23.

Tabel 23. Nilai Priority Vector

\begin{tabular}{cccccc}
\hline \multicolumn{7}{c}{ PV } & & \\
\hline Matematika & B.Ind & B.Ing & Biologi & Kimia & Fisika \\
\hline 0,06 & 0,17 & 0,33 & 0,13 & 0,07 & 0,07 \\
0,93 & 0,12 & 0,66 & 0,11 & 0,08 & 0,04 \\
& 0,14 & & 0,74 & 0,84 & 0,06 \\
& 0,55 & & & & 0,80 \\
\hline
\end{tabular}

4.2.6. Proses Dempster Rule's of Combination

Selanjutnya yaitu menghitung bobot untuk setiap alternatif, dengan menggunakan rumus Dempster's Rule of Combination. Adapun langkah-langkah untuk menentukan urutan hasil jurusan.

1. Irisan Kriteria Matematika (m1) dan Kriteria Bahasa Indonesia (m2)

1.1 Melakukan irisan terhadap Kriteria Matematika (m1) dan Kriteria Bahasa Indonesia (2) yang ditunjukkan pada Tabel 24. 
Tabel 24. Irisan kriteria matematika (m1) dan kriteria bahasa indonesia (m2)

\begin{tabular}{ccccc}
\hline $\mathbf{m 1} \cap \mathbf{m} \mathbf{2}$ & $\mathbf{I K}$ & $\mathbf{S K}$ & $\mathbf{P}$ & $\boldsymbol{\Theta}$ \\
\hline & 0,1720 & 0,1247 & 0,1483 & 0,5550 \\
$\mathbf{K M}, \mathbf{K U}, \mathbf{P}$ & $\varnothing$ & $\varnothing$ & $\mathrm{P}$ & $\mathrm{KM}, \mathrm{KU}, \mathrm{P}$ \\
$\mathbf{0 , 0 6 2 2}$ & 0,0107 & 0,0077 & 0,0092 & 0,0345 \\
$\boldsymbol{\Theta}$ & $\mathrm{IK}$ & $\mathrm{SK}$ & $\mathrm{P}$ & $\Theta$ \\
$\mathbf{0 , 9 3 7 8}$ & 0,1613 & 0,1169 & 0,1391 & 0,5205 \\
\hline
\end{tabular}

1.2 Hitung Nilai di Masing-Masing Alternatif

$m 3(I K)=\frac{0.1613}{1-(0.0107+0.0077)}=0.1643$

$m 3(S K)=\frac{0.1169}{1-(0.0107+0.0077)}=0.1191$

$m 3(P)=\frac{0.0092+0.1391}{1-(0.0107+0.0077)}=0.1511$

$m 3(K M, K U, P)=\frac{0.0345}{1-(0.0107+0.0077)}=0.0351$

$m 3(\Theta)=\frac{0.5205}{1-(0.0107+0.0077)}=0.5303$

2. Irisan Kriteria m3 dan Kriteria Bahasa Inggris $(\mathrm{m} 4)$

2.1 Melakukan irisan terhadap Kriteria m3 dan Kriteria Bahasa Inggris (m4) yang ditunjukkan pada Tabel 25.

2.2 Hitung nilai di masing-masing Alternatif

$\mathrm{m} 5(\mathrm{KM}, \mathrm{KU}, \mathrm{IK}, \mathrm{SK})=\frac{0.1763}{1-0.0502}=0.1856$

$\mathrm{m} 5(\mathrm{IK})=\frac{0.0546+0.1097}{1-0.0502}=0.1730$

$\mathrm{m} 5(\mathrm{SK})=\frac{0.0396+0.0795}{1-0.0502}=0.1254$

$\mathrm{m5}(\mathrm{P})=\frac{0.1009}{1-0.0502}=0.1062$ $\mathrm{m} 5(\mathrm{KM}, \mathrm{KU}, \mathrm{P})=\frac{0.0235}{1-0.0502}=0.0247$

$\mathrm{m} 5(\mathrm{KM}, \mathrm{KU})=\frac{0.0117}{1-0.0502}=0.0123$

$\mathrm{m} 5(\Theta)=\frac{0.3540}{1-0.0502}=0.3727$

Hal yang sama pada perhitungan Matematika dilakukan untuk mendapatkan nilai Alternatif. Urutan alternatif dari perhitungan terakhir ditunjukkan pada Tabel 25.

Tabel 25. Irisan kriteria $\mathrm{m} 3$ dan kriteria bahasa inggris (m4)

\begin{tabular}{ccc}
\hline $\mathbf{m 3} \cap \mathbf{m} \mathbf{4}$ & $\mathbf{K M}, \mathbf{K U}, \mathbf{I K}, \mathbf{S K}$ & $\boldsymbol{\Theta}$ \\
\hline $\mathbf{I K}$ & $\mathbf{0 , 3 3 2 5}$ & $\mathbf{0 , 6 6 7 5}$ \\
$\mathbf{0 , 1 6 4 3}$ & $\mathrm{IK}$ & $\mathrm{IK}$ \\
$\mathbf{S K}$ & 0,0546 & 0,1097 \\
$\mathbf{0 , 1 1 9 1}$ & $\mathrm{SK}$ & $\mathrm{SK}$ \\
$\mathbf{P}$ & 0,0396 & 0,0795 \\
$\mathbf{0 , 1 5 1 1}$ & $\varnothing$ & $\mathrm{P}$ \\
$\mathbf{K M}, \mathbf{K U}, \mathbf{P}$ & 0,0502 & 0,1009 \\
$\mathbf{0 , 0 3 5 1}$ & $\mathrm{KM}, \mathrm{KU}$ & $\mathrm{KM}, \mathrm{KU}, \mathrm{P}$ \\
$\mathbf{\Theta}$ & 0,0117 & 0,0235 \\
$\mathbf{0 , 5 3 0 3}$ & $\mathrm{KM}, \mathrm{KU}, \mathrm{IK}, \mathrm{SK}$ & $\Theta$ \\
& 0,1763 & 0,3540 \\
\hline
\end{tabular}

Dari hasil perhitungan di atas, maka diperoleh hasil akhir berupa urutan jurusan dari perbandingan antara nilai rapor dengan standar nilai minimum jurusan seperti pada Tabel 26.

Tabel 26 Urutan Jurusan

\begin{tabular}{cccc}
\hline No & Alternatif & Nilai & Urutan \\
\hline $\mathbf{1}$ & P & 0.1027 & 3 \\
$\mathbf{2}$ & SK & 0.1619 & 1 \\
$\mathbf{3}$ & IK & 0.1412 & 2 \\
$\mathbf{4}$ & KU & 0.0607 & 4 \\
$\mathbf{5}$ & KM & 0.0181 & 5 \\
$\mathbf{6}$ & KM, P & 0.0013 & \\
$\mathbf{7}$ & KM, IK & 0.0804 & \\
$\mathbf{8}$ & KM, SK & 0.0348 & \\
$\mathbf{9}$ & KM, KU & 0.0078 & \\
$\mathbf{1 0}$ & KM, IK, P & 0.0202 & \\
$\mathbf{1 1}$ & KM, KU, P & 0.0157 & \\
$\mathbf{1 2}$ & KM, KU, IK, SK & 0.1181 & \\
$\mathbf{1 3}$ & $\Theta$ & 0.237 & \\
\hline
\end{tabular}

Jurusan yang dipilih adalah urut dari nilai yang tertinggi sampai nilai yang terendah. Untuk penentuan jurusan diambil 3 (tiga) urutan teratas. Hal ini dilakukan karena dalam syarat pemilihan jurusan pada SNMPTN, siswa dapat memilih sebanyakbanyak nya 3 (tiga) program studi. Terlihat bahwa Urutan pertama adalah jurusan Sistem Komputer = 0.1619 , urutan kedua Ilmu Kelautan $=0.1412$, dan urutan ketiga Peternakan $=0.1027$. Nilai pada urutan ke 6 sampai 13 merupakan nilai ketidakpastian 
(uncertainty) atau nilai kemungkinan (plausibility). Hasil dari perhitungan metode DS/AHP sesuai dengan pilihan jurusan oleh siswa yaitu jurusan Ilmu Kelautan.

\subsection{Perbandingan Validitas Akurasi Sistem DS/AHP dengan $A H P$}

Pengujian Validitas Akurasi Sistem yang dilakukan dengan membandingkan antara fakta/jurusan yang dipilih oleh mahasiswa dengan hasil dari rekomendasi pemilihan program studi oleh sistem. Data yang digunakan sebanyak 29 orang mahasiswa semester dua yang terdiri dari enam mahasiswa jurusan Kesehatan Masyarakat, enam mahasiswa jurusan Kedokteran Umum, lima mahasiswa Jurusan Ilmu Kelautan, enam mahasiswa Peternakan, dan enam mahasiswa Sistem Komputer.

Tabel 27. Validasi Lima Jurusan dengan DS/AHP

\begin{tabular}{ccc}
\hline No & Jurusan & Validasi \\
\hline 1 & Kesehatan Masyarakat & $50 \%$ \\
2 & Kedokteran Umum & $100 \%$ \\
3 & Ilmu Kelautan & $80 \%$ \\
4 & Sistem Komputer & $83,33 \%$ \\
5 & Peternakan & $83,33 \%$ \\
\hline
\end{tabular}

Nilai validasi keseluruhan data :

$$
\begin{aligned}
& =\frac{80 \%+100 \%+50 \%+83,33 \%+83,33 \%}{5} \\
& =79,33 \%
\end{aligned}
$$

Tabel 28. Validasi lima jurusan dengan AHP

\begin{tabular}{ccc}
\hline No & Jurusan & Validasi \\
\hline 1 & Kesehatan Masyarakat & $66,67 \%$ \\
2 & Kedokteran Umum & $100 \%$ \\
3 & Ilmu Kelautan & $40 \%$ \\
4 & Sistem Komputer & $33,33 \%$ \\
5 & Peternakan & $66,67 \%$ \\
\hline
\end{tabular}

Nilai validasi keseluruhan data :

$$
\begin{aligned}
& =\frac{40 \%+100 \%+66,67 \%+33,33 \%+66,67 \%}{5} \\
& =61,33 \%
\end{aligned}
$$

Dari hasil perangkingan dengan menggunakan DS/AHP dan AHP, maka didapatkan nilai validasi DS/AHP adalah 79,33 dan nilai validasi AHP adalah $61,33 \%$.

\section{Kesimpulan}

Berdasarkan hasil penelitian dan pembahasan mengenai implementasi metode DS/AHP untuk pemilihan program studi calon mahasiswa, maka dapat diambil kesimpulan sebagai berikut :
1. Metode DS/AHP dapat diimplementasikan pada sistem pendukung keputusan pemilihan program studi calon mahasiswa.

2. Sistem dapat menghasilkan sebuah sistem informasi berupa urutan program studi berupa Jurusan Ilmu Kelautan, Kedokteran Umum, Kesehatan Masyarakat, Sistem Komputer dan Peternakan yang sesuai dengan standart nilai minimum dan nilai rapor pada semester 1-5.

3. Sistem pendukung keputusan ini mempunyai validitas nilai akurasi rata-rata $79.33 \%$ dari perhitungan validitas untuk 29 data dari jurusan yang dipilih dengan pengujian sistem dan didapatkan validitas untuk Jurusan Ilmu Kelautan $80 \%$, Kedokteran Umum 100\%, Kesehatan Masyarakat 50\%, Sistem Komputer $83.33 \%$, dan Peternakan $83.33 \%$.

\section{Daftar Pustaka}

Swastina, L., 2013. Penerapan algoritma C4.5 untuk penentuan jurusan mahasiswa. Jurnal Gema Aktualita, vol 2, 93-98.

Hua, Z., Gong, B., Xu, X., 2008. A DS-AHP approach for multi-attribute decision making problem with incomplete information. Expert Systems with Applications, 2221-2227.

Hermawan, J., 2005. Membangun Decision Support System. Penerbit Andi Yogyakarta.

Turban, E., Aronson, J.E., dan Liang, T.P., 2005. Decision Support System And Intelligent System. Penerbit Andi, Yogyakarta.

Beynon, M., 2001. An expert system for multikriteria decision making using Dempster Shafer theory. Expert Systems with Applications, 357367.

Beynon, J.M., 2008. Encyclopedia of Decision Making and Decision Support Technologies, IGI Global Snippet.

Marimin., 2004. Teknik dan Aplikasi Pengambilan Keputusan Kriteria Majemuk. Grassindo, Jakarta.

Kousalya, P., Reddy, G.M., Supraja, S., Prasad, V.S., 2012. Analytical hierarchy process approach -an application of engineering education. Mathematica Aeterna, 2 (10): 861-878.

Goshal, S.K., Naskar, S.K., Bose, D., 2011. AHP in assessing performance of diploma institutes - A case study. Jurnal of Technical Education and Training, Vol. 3 No 2. 